\title{
Coincidence Positron Imaging of the Liver and Heart following Rectal Administration of ${ }^{13} \mathrm{~N}$-ammonia in Liver Cirrhosis ${ }^{\dagger}$
}

\author{
Nobuo FukudA, Yukio Tateno, Tomoyuki Rikitake, \\ Toru Matsumoto, Takehiro TomitanI, Kazutoshi SUZUKI, \\ Hirofumi KOEN*, Hirotaka MUSHA* and Kunio OKUDA* \\ National Institute of Radiological Sciences, Anagawa, Chiba-shi 280, Japan \\ * Department of Medicine, Chiba University School of Medicine \\ Inohana-cho, Chiba-shi 280, Japan \\ Received September 16, 1977
}

Rectal administration of ammonium salt as done in the rectal ammonia tolerance test, is followed by rapid absorption of ammonia, which is cleared by the normal liver in a single passage ${ }^{11}$. Therefore, ammonia concentration in blood should not rise appreciably in the hepatic vein and systemic arteries.

In the presence of porta-systematic collaterals, some of the absorbed ammonia will bypass the hepatic cells through intra-and/or extrahepatic shunts and go into systemic circulation, thus resulting in an elevation of arterial concentration of ammonia.

${ }^{13} \mathrm{~N}$-ammonia is a short-lived $\left(T_{1 / 2}=10 \mathrm{~min}\right)$ cyclotron produced $\beta^{+}$emitter.

We expected that sequential coincidence positron imaging of the liver and heart following rectal administration of ${ }^{13} \mathrm{~N}$-ammonia would be of diagnostic value in patients with liver cirrbosis or idiopathic portal hypertension.

Recently, Hazenberg, et al. reported on rectal ${ }^{13} \mathrm{~N}$-ammonia test $\left({ }^{13} \mathrm{~N}\right.$-liver/heart ratio) by using a conventional Anger type $\gamma$-camera with a 1000 hole high energy collimator and a 4096 channel analyzer with a magnetic tape

$\dagger{ }^{13} \mathrm{~N}-ア ン モ ニ ア の$ 経直腸投与後の肝硬変患者の肝 と心の同時計数陽電子イメーシシング。福田信男, 館野之男, 力武知之, 松本徹, 富谷武浩, 鈴木和 年，高圓博文*，武者広隆*，奥田邦雄*：放射線医 学総合研究所, 280 千葉市穴川4-9-1，*千葉大学 医学部第一内科, 280 千葉市亥鼻町 1-8-1 recorder for body measurement ${ }^{2,3)}$. Under these conditions, the spatial resolution of their detecting system, seems to be insufficient for the determination of ${ }^{13} \mathrm{~N}-\mathrm{liver} / \mathrm{heart}$ ratio.

Unlike their instrumentation, we used a novel type positron camera which has enough spatial resolution for the same purpose.

\section{Materials and Methods}

1) Production of ${ }^{13} \mathrm{~N}$-labeled ammonia ${ }^{4)}$

Irradiation was carried out on the NIRS cyclotron. Distilled water was bombarded with a $20 \mu \mathrm{A}$ external proton beam of 20 $\mathrm{MeV}$.

The ${ }^{13} \mathrm{~N}$-containing solution was introduced into a reduction vessel containing Devarda's alloy and $\mathrm{NaOH}$, and ${ }^{13} \mathrm{~N}$-labeled ammonia was isolated by distillation into a vessel containing $5 \mathrm{~m} l$ of a $0.9 \%\left(\mathrm{NH}_{4}\right)_{2} \mathrm{CO}_{3}$ solution.

2) Apparatus ${ }^{5)}$

A new positron camera interfaced with an on-line computer system (TOSBAC 3400 model 31) consisting of a focal detector of hexagonal multi-crystal array and a conventional Anger-type $\gamma$-camera(TOSHIBA, GCA202, delayed line type), was used for positron imaging of the liver and heart.

Some characteristics of the positron camera are; (1) maximum attainable high counting rate of about $2.55 \mathrm{kcps}$, (2) detec- 
Table 1 Wedged hepatic venous pressure (WHVP), portal venous pressure (PVP), percentage retention of indocyanine green $15 \mathrm{~min}$ after i.v. injection $\left(\mathrm{ICG}_{\mathrm{R}(\mathrm{s})}\right.$ ), and the heart/ liver ratio of ${ }^{13} \mathrm{~N}$-activity per unit area $15 \mathrm{~min}$ after rectal administration of ${ }^{13} \mathrm{~N}$-ammonia $\left(\mathrm{H} / \mathrm{L}_{15}\right)$

\begin{tabular}{|c|c|c|c|c|c|c|c|c|c|c|}
\hline Name & Sex & Age & Clinical diagnosis & $\begin{array}{l}\text { Grade } \\
\text { of } \\
\text { varices }\end{array}$ & Ascites & $\begin{array}{c}\text { serum } \\
\gamma-\text { globulin } \\
(\%)\end{array}$ & $\begin{array}{c}\mathrm{WHVI} \\
(\mathrm{mm} \\
\left.\mathrm{H}_{2} \mathrm{O}\right) \\
\end{array}$ & $\begin{array}{c}\text { PVP } \\
\left(\mathrm{mm}^{2}\right. \\
\left.\mathrm{H}_{2} \mathrm{O}\right)\end{array}$ & $\begin{array}{l}\operatorname{ICG}_{(\% 15)} \\
(\%)\end{array}$ & $\mathrm{H} / \mathrm{L}_{15}$ \\
\hline T. O. & $\mathrm{F}$ & 68 & Essential tremor & $(-)$ & $(-)$ & 11.6 & & & & 0.18 \\
\hline F.T. & M & 35 & Essential hypertension & $(-)$ & $(-)$ & & & & & 0.43 \\
\hline B. Y. & M & 70 & $\begin{array}{l}\text { Convalescent stage of } \\
\text { acute hepatitis }\end{array}$ & $(-)$ & $(-)$ & 15.5 & & & 16.0 & 0.2 \\
\hline H. I. & $\mathrm{F}$ & 50 & "I & $(-)$ & $(-)$ & 21.6 & & & 7.5 & 0.17 \\
\hline T. I. & $\mathrm{F}$ & 46 & Chronic hepatitis & $(-)$ & $(-)$ & 18.0 & & & 5.0 & 0.40 \\
\hline I. S. & M & 59 & 11 & $(-)$ & $(-)$ & 24.0 & & & 17. 0 & 0.35 \\
\hline Y.S. & M & 44 & $\prime \prime$ & $(-)$ & $(-)$ & 19.8 & & & 14.5 & 0.32 \\
\hline Y. K. & $\mathrm{F}$ & 48 & Liver cirrhosis & (W) & $( \pm)$ & 32.5 & 370 & & 62.5 & 0.81 \\
\hline T. U. & M & 45 & "I & $(H)$ & $(-)$ & 31.8 & 330 & 340 & 30.0 & 0.66 \\
\hline M. S. & M & 41 & "I & $(+)$ & $(-)$ & 32.4 & 320 & & 65.0 & 0.72 \\
\hline S. H. & M & 42 & "I & $(+)$ & $(-)$ & 21.6 & 280 & & 34.0 & 0.53 \\
\hline T.N. & M & 43 & $\prime \prime$ & $(H)$ & $(+)$ & & 370 & & 40.5 & 1. 29 \\
\hline Y.N. & $\mathrm{M}$ & 33 & $\prime \prime$ & $(H)$ & $(+)$ & 28.7 & 120 & 290 & 48.5 & 1. 11 \\
\hline H. T. & M & 49 & $\prime \prime$ & $(H)$ & $( \pm)$ & 33 & 380 & 402 & 21.0 & 1. 12 \\
\hline T. Y. & $\mathrm{F}$ & 46 & 11 & & $(+)$ & 35.2 & 400 & & 59.0 & 0.88 \\
\hline M. N. & $\mathrm{F}$ & 57 & $\begin{array}{l}\text { Idiopathic portal hyper- } \\
\text { tension }\end{array}$ & $(H)$ & $(-)$ & & 205 & & 27.5 & 0.90 \\
\hline M. H. & $\mathrm{F}$ & 46 & 11 & $(+)$ & $(-)$ & 16.9 & 110 & 340 & 4.0 & 0.73 \\
\hline T. H. & $\mathrm{M}$ & 35 & $\prime \prime$ & (H) & $(-)$ & 17.9 & 130 & 410 & 8.0 & 0.70 \\
\hline
\end{tabular}

tion efficiency of $0.6 \sim 0.9$ dots $/ \mathrm{sec} / \mu \mathrm{Ci}$, (3) spatial resolution of $6 \sim 9 \mathrm{~mm}$ (FWHM)(those figures depend on the distance from the collimator surface of the $\gamma$-camera to source), and (4) area of uniform sensitivity of about $20 \mathrm{~cm}$ in diameter at the depth of $20 \mathrm{~cm}$ from collimator surface.

\section{3) Procedure}

Fifteen-thirty $\mathrm{mCi}$ of ${ }^{13} \mathrm{~N}$-ammonia dissolved in $10 \mathrm{~m} l$ of a solution buffered at $\mathrm{pH} 8.1$ $\left(\mathrm{Na}^{+}: 130 \mathrm{mEq} / l, \mathrm{~K}^{+}: 20 \mathrm{mEq} / l, \mathrm{Cl}^{-}: 100 \mathrm{mEq}\right.$ $/ l, \mathrm{HCO}_{3}^{-}: 50 \mathrm{mEq} / l$ ) was administered via a catheter into the rectum previously cleaned by enema. The localization of the liver and heart had previously been determined by ${ }^{99 m}$ Tc-phytate imaging and ${ }^{89 m}$ Tc-phytate angiography, respectively.

\section{4) Patients (Table 1)}

The control group (patient without varices and ascites) consisted of a patient with essential, tremor, a patient with essential hypertension, three patients with chronic hepatitis and two patients in the convales- cent stage of acute hepatitis. Eight patients with liver cirrhosis, and three patients with idiopathic portal hypertension were also studied.

\section{Results}

In all subjects, ${ }^{13} \mathrm{~N}$-radioactivity appeared in the liver in about 1 min after rectal administration of ${ }^{13} \mathrm{~N}$-ammonia.

In control subjects, ${ }^{13} \mathrm{~N}$-liver activity reached a maximum in about $20 \mathrm{~min}$ and then decreased gradually; the heart activity was much lower and increased gradually up to 50 min. A typical example of sequential positron imaging of the liver and heart in a control subjects (T.O.) is shown in Fig. $1 \mathrm{~A}$. ${ }^{13} \mathrm{~N}$-radioactivity clearly visualized the liver within $5 \mathrm{~min}$ after administration while it was difficult to discriminate the heart image.

In patients with liver cirrhosis expected to have porta-systemic collateral circulation, however, it was difficutl to discriminate the faint liver image from the lung and the 
heart image as shown in Fig. 1B. The liver activity in the patient with cirrhosis continued to increase following the rapid rise during the first $10 \mathrm{~min}$. The radioactivity per unit area at $15 \mathrm{~min}$ after rectal administration of ${ }^{13} \mathrm{~N}$-ammonia are shown with the other data in Table 1.

\section{Discussion}

This work was undertaken to evaluate the relevance of sequential coincidence positron imaging of the liver and heart following rectal administration of ${ }^{13} \mathrm{~N}$-ammonia for the detection of porta-systemic collateral circulation. While conclusive comment is not yet in order because of inadequate case studies in the present work, the accumulation of ${ }^{13} \mathrm{~N}$-ammonia to the liver with cirrhosis was found to be much lower than that in the control without varices and ascites. It may be attributed to porta-systemic collateral cir-
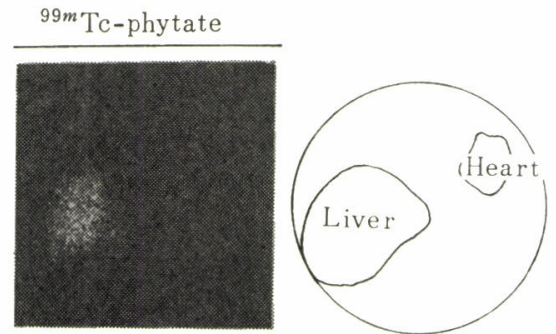

${ }^{13} \mathrm{~N}$-ammonia

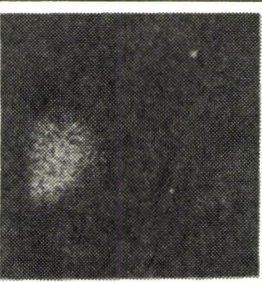

$0-5 \mathrm{~min}$

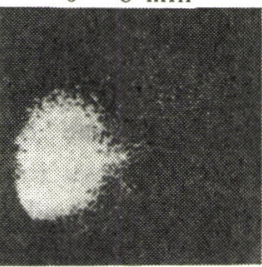

$30-35 \mathrm{~min}$

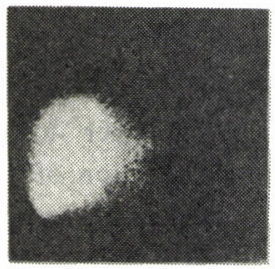

$15-20 \mathrm{~min}$

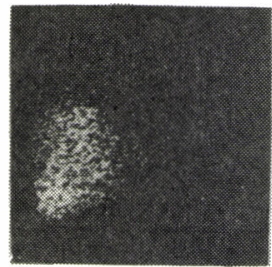

$45-50 \mathrm{~min}$

(A) culation and decreased effective intrahepatic portal vascularity, as well as to reduced number of functioning hepatocytes in liver cirrhosis.

The heart activity in liver cirrhosis seems to be much higher than the control. It may represent accumulation of ${ }^{13} \mathrm{~N}$-ammonia bypassing the hepatocytes in the liver with cirrhosis to reach the cardiac muscle which is known to take up ammonia efficiently ${ }^{6)}$.

In the evaluation of porta-systemic collateral circulation, determination of ${ }^{13} \mathrm{~N}$-heart /liver ratio overcomes difficulty associated with the variations in dosage and absorption in each patient. The observed increase in this ratio in cirrhosis may reflect the hepatofugal circulation and decreased intrahepatic portal vascularity, and decreased number of functioning hepatocytes, and have a signifcance different from that of dye retention tests.

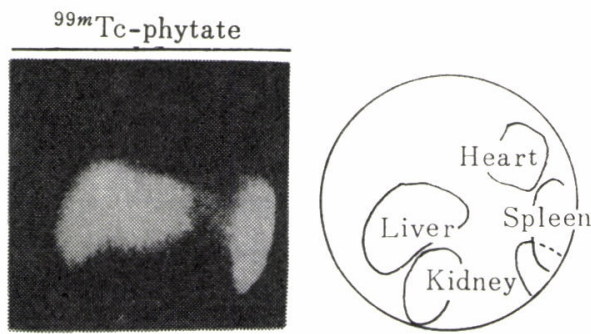

${ }^{13} \mathrm{~N}-\mathrm{ammonia}$

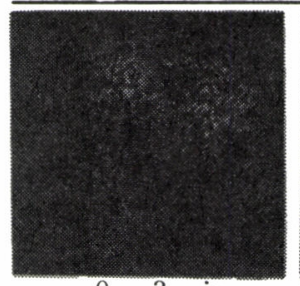

$0-3 \mathrm{~min}$
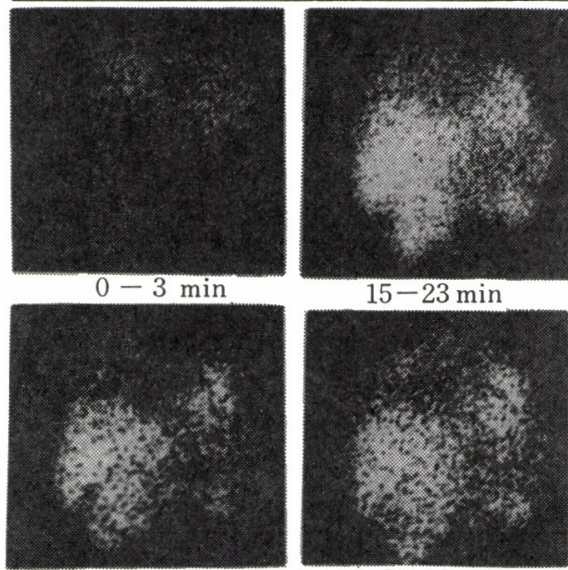

$33-43 \mathrm{~min}$

(B)

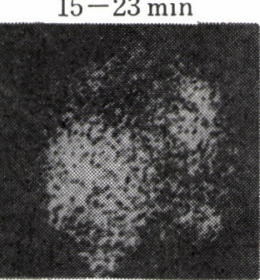

$43-53 \mathrm{~min}$

Fig. 1 Sequential coincidence positron image of the liver and heart following rectal administration of ${ }^{18} \mathrm{~N}$-ammonia with ${ }^{99 m} \mathrm{Tc}$-phytate image and the illustration.

A. A patient (T.O.) with essential tremor.

B. A patient (Y.K.) with liver cirrhosis. 
The present method is commendable for its non-invasiveness, quick radiation decay, and rapidity in having the results.

\section{References}

1) Brosnan, J.T.: Factors affecting intracellular ammonia concentration in liver. In The Urea Cycle. Grisolia, S., Baguerana, R., Mayor, F. eds., Wiley Interscinces 1976, p. 443 57 .

2) Hazenberg, H.J.A., Gips, C.H., et al.: Acta Hepato-Gastroenterol., 23, 308 18(1976)
3) Hazenberg, H.J.A., Gips, C.H., Beekhuis, H., et al.: ibid., 23, 319 30 (1976)

4) Suzuki, K., Iwata, R.: Int. J. Appl.Radiat. \& Isotopes,28, 663 65 (1977)

5) Tomitani, T., Tanaka, E., Nohara, N.: Radioisotopes, 25, 693 98 (1976) (in Japanese)

6) Walsh, W.F., Fill, H.R., Harper, P.V.: Nitrogen-13-labeled ammonia for myocardial imaging. Semin. Nucl. Med., 7, 5966 (1977) 